\title{
The Effects of Methanol and Ethanol on the States of Ionic Hydration of Lithium Fluoride in Aqueous Solution-Solubility of Lithium Fluoride and Electroconductivity of its Solutions*
}

\author{
Goro WADA**, Chikako ITO*** and Kimiko HorIE***
}

Among all alkali halides, $\mathrm{LiF}$ has special natures that its cation and anion are both the smallest in size respectively and that its solubility in water is extraordinarily small. Since the smaller the ions, the stronger is the interaction between an ion and solvent molecules, the behavior of $\mathrm{LiF}$ in aqueous solution (solubilities, electric conductivities, etc.) were measured, when methanol or ethanol were added to the solution. From the results, the state of ionic hydration of LiF was deduced.

$\mathrm{LiF}$ used was prepared from $\mathrm{LiCl}$ and $\mathrm{KF}$. The solubilities were measured by the method of weighing the residue after evaporating the definite quantity of saturated solution to dryness on a glass evaporatingdish. The electric conductivity of the saturated solutions was also measured, being compared with that of $\mathrm{NaCl}$ aqueous solution as the standard. Measurements were carried out within the whole range of alcohol concentration at $18^{\circ}, 25^{\circ}$, and $35^{\circ} \mathrm{C}$, the results of which are listed in tables 1 and 2 .

The solubility of $\mathrm{LiF}$ is remarkably decreased by the addition of alcohol, exhibiting as small as nearly $1 / 5$ value of that in pure water at about $5 \mathrm{~mol} \%$ of alcohol, and almost $1 / 10$ in pure alcohol. The temperature coefficient of the solubility decreases as the alcohol concentration increases, and reaches almost

Table I Mixed Solvent of Methanol and Water

\begin{tabular}{|c|c|c|c|c|c|}
\hline $\begin{array}{l}\text { Concentration } \\
\text { of Methanol } \\
(\text { mol \%) }\end{array}$ & $\begin{array}{c}\text { Temperature } \\
\left({ }^{\circ} \mathrm{C}\right)\end{array}$ & $\begin{array}{l}\text { Viscosity } \\
\text { (centipoise) }\end{array}$ & $\begin{array}{l}\text { Density } \\
\left(\mathrm{g} / \mathrm{cm}^{3}\right)\end{array}$ & $\begin{array}{l}\text { Solubility } \\
(\mathrm{mol} / \mathrm{mol}- \\
\left.\text { solvent } \times 10^{4}\right)\end{array}$ & $\begin{array}{l}\text { Equivalent } \\
\text { electric conductivity } \\
\left(\Omega^{-1} \mathrm{~cm}^{2} \text { val }^{-1}\right)\end{array}$ \\
\hline \multirow{3}{*}{0.00} & 18 & 1.062 & 0.9998 & 8.52 & 61.0 \\
\hline & 25 & 0.894 & 0.9984 & 8.74 & 72.5 \\
\hline & 35 & 0.701 & 0.9955 & 9.39 & 96.6 \\
\hline \multirow{3}{*}{5.12} & 18 & 1.343 & 0.9851 & 6.01 & 57.4 \\
\hline & 25 & 1.107 & 0.9833 & 6.43 & $(76.4)$ \\
\hline & 35 & 0.843 & 0.9799 & 7.02 & 78.3 \\
\hline \multirow{3}{*}{10.07} & 18 & 1.601 & 0.9736 & 5.08 & 43.3 \\
\hline & 25 & 1.300 & 0.9707 & 5.23 & 51.7 \\
\hline & 35 & 0.980 & 0.9668 & 5.67 & 69.5 \\
\hline \multirow{3}{*}{14.99} & 18 & 1.802 & 0.9630 & 4.23 & 39.4 \\
\hline & 25 & 1.449 & 0.9587 & 4.61 & 48.4 \\
\hline & 35 & 1.067 & 0.9545 & 4.93 & 53.4 \\
\hline \multirow{3}{*}{19.72} & 18 & 1.903 & 0.9520 & - & 34.7 \\
\hline & 25 & 1.549 & 0.9488 & - & 42.4 \\
\hline & 35 & 1.134 & 0.9432 & - & 57.3 \\
\hline \multirow{3}{*}{24.92} & 18 & 1.959 & 0.9413 & - & 30.5 \\
\hline & 25 & 1.570 & 0.9371 & - & 38.0 \\
\hline & 35 & 1.162 & 0.9307 & - & 47.6 \\
\hline \multirow{3}{*}{29.96} & 18 & 1.934 & 0.9301 & - & 29.2 \\
\hline & 25 & 1.570 & 0.9257 & - & 37.9 \\
\hline & 35 & 1.161 & 0.9190 & - & 52.3 \\
\hline \multirow{3}{*}{100} & 18 & 0.597 & 0.7934 & - & 36.9 \\
\hline & 25 & 0.539 & 0.7857 & - & $(17.8)$ \\
\hline & 35 & 0.456 & 0.7774 & - & 32.3 \\
\hline
\end{tabular}

* Ionic Solvation in Solutions (Part 6)

** Department of Chemistry, Faculty of Science, Kobe University, Kobe, Japan

*** Kobe Women's College of Pharmacy, Kobe, Japan

The original written in Japanese can be seen in J. Electrochem. Soc. Japan, 28,58 (1960). 
Table 2 Mixed Solvent of Ethanol and Water

\begin{tabular}{|c|c|c|c|c|c|}
\hline $\begin{array}{l}\text { Concentration } \\
\text { of Ethanol } \\
(\mathrm{mol} \%)\end{array}$ & $\begin{array}{c}\text { Temperature } \\
\left({ }^{\circ} \mathrm{C}\right)\end{array}$ & $\begin{array}{l}\text { Viscosity } \eta \\
\text { (centipoise) }\end{array}$ & $\begin{array}{l}\text { Density } \rho \\
\left(\mathrm{g} / \mathrm{cm}^{3}\right)\end{array}$ & $\begin{array}{l}\text { Solubility } \\
(\mathrm{mol} / \mathrm{mol}- \\
\left.\text { solvent } \times 10^{4}\right)\end{array}$ & $\begin{array}{c}\text { Equivalent } \\
\text { electric conductivity } \\
\left(\Omega^{-1} \text { cm }^{2} \text { val }^{-1}\right)\end{array}$ \\
\hline \multirow{3}{*}{4.98} & 18 & 1.717 & 0.9804 & 5.11 & - \\
\hline & 25 & 1.371 & 0.9785 & 5.51 & 58.1 \\
\hline & 35 & 1.011 & 0.9749 & 6.00 & 72.7 \\
\hline \multirow{3}{*}{9.91} & 18 & 2.420 & 0.9673 & 3.80 & 31.1 \\
\hline & 25 & 1.846 & 0.9638 & 3.93 & 38.5 \\
\hline & 35 & 1.304 & 0.9585 & 4.29 & 52.7 \\
\hline \multirow{3}{*}{20.03} & 18 & 3.041 & 0.9395 & - & 20.1 \\
\hline & 25 & 2.301 & 0.9340 & - & 23.9 \\
\hline & 35 & 1.599 & 0.9273 & - & 46.9 \\
\hline \multirow{3}{*}{29.84} & 18 & 2.960 & 0.9117 & - & 15.6 \\
\hline & 25 & 2.290 & 0.9052 & - & 21.9 \\
\hline & 35 & 1.621 & 0.8976 & - & 30.9 \\
\hline \multirow{3}{*}{99.95} & 18 & 1.229 & 0.7911 & - & - \\
\hline & 25 & 1.069 & 0.7853 & - & - \\
\hline & 35 & 0.862 & 0.7778 & - & - \\
\hline
\end{tabular}

Table 3 Apparent Ionic Radii ( $r$ ) and Apparent Activation Energies of Electric Conductivity $(E)$

\begin{tabular}{|c|c|c|c|c|c|c|c|}
\hline $\begin{array}{l}\text { Conc. of } \\
\text { Methanol } \\
(\mathrm{mol} \%)\end{array}$ & $\begin{array}{l}\text { Temp. } \\
\left({ }^{\circ} \mathrm{C}\right)\end{array}$ & $\begin{array}{c}r \\
(\AA)\end{array}$ & $\begin{array}{c}E \\
(\mathrm{kcal} / \mathrm{mol})\end{array}$ & $\begin{array}{c}\text { Conc. of } \\
\text { Ethanol } \\
(\mathrm{mol} \%)\end{array}$ & $\begin{array}{l}\text { Temp. } \\
\left({ }^{\circ} \mathrm{C}\right)\end{array}$ & $\begin{array}{c}r \\
(\AA)\end{array}$ & $\underset{(\mathrm{kcal} / \mathrm{mol})}{E}$ \\
\hline 0.00 & $\begin{array}{l}18 \\
25 \\
35\end{array}$ & $\begin{array}{l}2.5 \\
2.5 \\
2.4\end{array}$ & 5 & 0.00 & $\begin{array}{l}18 \\
25 \\
35\end{array}$ & $\begin{array}{l}2.5 \\
2.5 \\
2.4\end{array}$ & 5 \\
\hline 5.15 & $\begin{array}{l}18 \\
25 \\
35\end{array}$ & $\begin{array}{c}2.1 \\
(1.9) \\
2.5\end{array}$ & 4 & 4.98 & $\begin{array}{l}18 \\
25 \\
35\end{array}$ & $\begin{array}{r}- \\
2.0 \\
2.2\end{array}$ & 4 \\
\hline 10.07 & $\begin{array}{l}18 \\
25 \\
35\end{array}$ & $\begin{array}{l}2.4 \\
2.4 \\
2.4\end{array}$ & 5 & 9.91 & $\begin{array}{l}18 \\
25 \\
35\end{array}$ & $\begin{array}{l}2.2 \\
2.3 \\
2.4\end{array}$ & 6 \\
\hline 14.99 & $\begin{array}{l}18 \\
25 \\
35\end{array}$ & $\begin{array}{l}2.3 \\
2.3 \\
2.9\end{array}$ & (3) & & & & \\
\hline 19.72 & $\begin{array}{l}18 \\
25 \\
35\end{array}$ & $\begin{array}{l}2.5 \\
2.5 \\
2.5\end{array}$ & 6 & 20.03 & $\begin{array}{l}18 \\
25 \\
35\end{array}$ & $\begin{array}{l}2.7 \\
3.0 \\
2.2\end{array}$ & 9 \\
\hline 24.92 & $\begin{array}{l}18 \\
25 \\
35\end{array}$ & $\begin{array}{l}2.8 \\
2.8 \\
3.0\end{array}$ & 5 & & & & \\
\hline 29.96 & $\begin{array}{l}18 \\
25 \\
35\end{array}$ & $\begin{array}{l}3.0 \\
2.8 \\
2.7\end{array}$ & 7 & 29.84 & $\begin{array}{l}18 \\
25 \\
35\end{array}$ & $\begin{array}{l}3.6 \\
3.3 \\
3.3\end{array}$ & 7 \\
\hline 100 & $\begin{array}{l}18 \\
25 \\
35\end{array}$ & $\begin{array}{r}7.5 \\
(17.2) \\
(11.1)\end{array}$ & - & & & & \\
\hline
\end{tabular}

zero at higher concentration than $30 \mathrm{~mol} \%$. The mean apparent radius of migrating ions according to the Walden's law is constantly about $2.4 \AA$ up to near $20 \mathrm{~mol} \%$, over which the radius increases abruptly, as shown in Table 3. The apparent activation energy of ionic conduction of the solution derived from the equivalent electric conductivity of $\mathrm{LiF}$ is approximately equal to that of ionic diffusion in water at lower alcoholic concentration, but grows higher at the higher concentration than $20 \sim 30 \mathrm{~mol}$ \%. As will be seen also in table 4, when $1 \mathrm{~mol}$ of $\mathrm{LiF}$ is transferred from an aqueous solution to an alcoholic aqueous solution, $\Delta F$ is always positive, the absolute value of which at $10 \mathrm{~mol} \%$ is larger 
Table 4 Thermodynamic Functions When LiF is transferred from Pure Water Phase to Mixed-Solvent Phase of Water and Alcohol

\begin{tabular}{c|c|c|c|c}
\hline \hline Alcohol & $\begin{array}{c}\text { Concentration } \\
(\mathrm{mol} \%)\end{array}$ & $\begin{array}{c}\Delta F \\
(\mathrm{cal} / \mathrm{mol})\end{array}$ & $\begin{array}{c}\Delta H \\
(\mathrm{cal} / \mathrm{mol})\end{array}$ & $\begin{array}{c}\Delta S \\
(\mathrm{cal} / \mathrm{deg} \cdot \mathrm{mol})\end{array}$ \\
\hline \multirow{2}{*}{ Methanol } & 5.15 & 180 & 510 & -1.1 \\
& 10.07 & 310 & -80 & -1.3 \\
\hline \multirow{2}{*}{ Ethanol } & 4.98 & 480 & -30 & -1.0 \\
\hline
\end{tabular}

than that at $5 \mathrm{~mol} \% . \Delta S$ at $5 \mathrm{~mol} \%$ is positive, while that at $10 \mathrm{~mol} \%$ is negative. Accordingly, in the solvation equilibrium around ions,

$$
\mathrm{H}_{2} \mathrm{O} \text { (solvated) }+\mathrm{Alc} \text { (free) } \rightleftarrows \mathrm{H}_{2} \mathrm{O} \text { (free) }+\mathrm{Alc} \text { (solvated) }
$$

the equilibrium is fairly inclined to the left-hand side of the equation, water molecules being selectively concentrated in the vicinity of ions. From the informations concerning $\Delta S$, the following descriptions can be given that, at $5 \mathrm{~mol} \%$ of alcohol, $\Delta S$ would be positive as the result of relaxation and agitation of the ionic solvation layer according to the introduction of alcohol molecules, and that, at $10 \mathrm{~mol} \%$, on the other hand, $\Delta S$ would be rather negative, on account of both the selective solvation in the ionic solvation layers and the strengthening effect of quasi-crystalline structure of ice ("iceberg") under the circumstances far off from ions.

After all, from the above-mentiond results, alcohol molecules are imagined to begin to be solvated conspicuously, when the concentration of alcohol exceeds $10 \sim 20 \mathrm{~mol} \%$, and the alcoholic solvation to ions seems to affect some properties more effectively in case of ethanol than in case of methanol.

(Received May 25, 1958) 